\title{
THE USE OF RAINBOW TROUT ONCORHYNCHUS MYKISS IN EARLY ONTOGENESIS FOR THE WATER TOXICITY ASSESSMENT
}

\author{
Nijolè Kazlauskiené $\dot{e}^{\prime}$ \\ Milda Zita Vosylien $\dot{e}^{l}$ \\ EglèRatkelyte ${ }^{\prime}$ \\ Vilmanté Karlavičien $\dot{e}^{23}$ \\ William Hogland ${ }^{3}$ \\ 'Institute of Ecology of Vilnius University, Lithuania \\ ${ }^{2} V i l n i u s$ Gediminas Technical University, Lithuania \\ ${ }^{3}$ University of Kalmar, Sweden
}

\begin{abstract}
Toxicity of some heavy metals (HM), heavy metal model mixture (HMMM), orimulsion, crude oil and water of some biotopes of Lake Druksiai was evaluated by use of the fish in all stages of development (embryos, larvae, adult fish). The rainbow trout was very sensitive test-organism to the effect of different kind pollutants and the most sensitive to the impact of pollutants were fish at early stages of development i.e. larvae and embryos. The integrated biological parameters of fish at all stages of development (survival, growth rate, and relative mass increase) were the most sensitive ones. In accordance with the sensitivity to the impact of heavy metals, animals in the earliest stages of their development were more sensitive than plants, but the plants in some cases were more sensitive to heavy metals than adult fish. Therefore, plants as well as animals rainbow trout (Oncorhynchus mykiss) of different life stages, as test-organisms, are recommended for the inclusion of the complex biotests for the assessment of the impact of heavy metals. The complex of the most sensitive parameters investigated of rainbow trout can be successfully used for the water toxicity assessment containing different kind pollutants. The data obtained let predict the impact of pollution not only to the physiological status of aquatic organisms but as well as to their survival in natural water bodies.
\end{abstract}

\section{KEYWORDS}

Rainbow trout; Embryos; Larvae; Adult; Biological parameters; Heavy metals; Heavy metal model mixture; Crude oil; Orimulsion; Water of biotopes; Acute toxicity; Long-term toxicity 


\author{
Kalmar ECO-TECH ' 05 and \\ The Second Baltic Symposium on Environmental Chemistry \\ KALMAR, SWEDEN, November 28-30, 2005
}

\title{
1 INTRODUCTION
}

Industrial waste waters discharging into natural aquatic systems usually contain complexes of heavy metals, however majority of ecotoxicological studies on the metal toxicity evaluate effects of single metals on fish and usually on one level of biological parameters [1,2]. Complex studies of the toxicity of effluents using different fish species and evaluating their biochemical, physiological and pathological parameters demonstrated different sensitivity of indices studied $[3,4,5]$ and the authors emphasised the necessity of assessment of a complex of various level biological parameters of fish organism. Thereby contemporary approach in toxicity testing of effluents should be based on short and long-term complex studies of parameters various biological level of fish [6,7].

Organisms more often than not are much more sensitive and quick-to-react to low concentrations of doxicants than chemical and physical methods. Therefore, over the last years, while making an ecological examination and environmental monitoring, methods of biological impact assessment are widely applied and improved by using sensitive test organisms. However, the most comprehensive evaluation of sublethal toxicity of effluents is achieved when studies are performed on fish in all stages of development. Toxicity tests on fish in ontogenesis have shown more reliable detection and better quantification of heavy metal mixture $[8,9,10]$ or single metal toxicity $\left[\begin{array}{lll}11 & 12 & 13\end{array} 14\right]$. The authors proposed to use embryo-larval tests for predicting aftereffects of heavy metals and their mixtures to fish organism and even to population $[15,16]$.

Our previous studies demonstrated the particular sensitivity of fish in early ontogenesis to different kinds of plants, e.g. orimulsion, heavy fuel oil, crude oil and even to oil spill dispersant (SIMPLE GREEN) $[17,18,19]$.

The objective of our study was to evaluate the toxicity of some heavy metals (HM), heavy metal model mixture (HMMM), orimulsion, crude oil and water of some biotopes of Lake Druksiai to fish in all stages of development (embryos, larvae, adult fish); to determine and compare the sensitivity of fish in some development stages to toxicants under study with the sensitivity of different phylogenetic level organisms.

\section{MATERIAL AND METHODS}

\subsection{Chemicals under study}

Separate heavy metal stock solutions were prepared in distilled water by use of the following chemically pure (reagent grade) substances: $\mathrm{CuSO}_{4} \cdot 5 \mathrm{H}_{2} \mathrm{O}, \mathrm{ZnSO}_{4} \cdot 7 \mathrm{H}_{2} \mathrm{O}$ the final concentrations being recalculated according to the amount of heavy metal ions.

Heavy metal model mixture (HMMM) consisting of seven heavy metals was investigated. The formation of model mixture was carried out basing on available analytical data of average annual amounts of representative heavy metals in cooling waste waters discharging from lgnalina Nuclear Power Plant (Lithuania) into the Lake Druksiai during 1996. The stock solution of HMMM was prepared in acidified distilled water by use of the following chemically pure substances: $\mathrm{CuSO}_{4} \cdot 5 \mathrm{H}_{2} \mathrm{O}, \mathrm{ZnSO}_{4} \cdot 7 \mathrm{H}_{2} \mathrm{O}, \mathrm{NiSO}_{4} \cdot 7 \mathrm{H}_{2} \mathrm{O}, \mathrm{K}_{2} \mathrm{Cr}_{2} \mathrm{O}_{7}, \mathrm{~Pb}\left(\mathrm{NO}_{3}\right)_{2}, \mathrm{Cd}\left(\mathrm{CH}_{3} \mathrm{COO}\right)_{2} \cdot 2 \mathrm{H}_{2} \mathrm{O}$, $\mathrm{MnSO}_{4} \cdot 5 \mathrm{H}_{2} \mathrm{O}$, the final concentration being recalculated according to the amount of heavy metal 


\author{
Kalmar ECO-TECH '05 and \\ The Second Baltic Symposium on Environmental Chemistry \\ KALMAR, SWEDEN, November 28-30, 2005
}

ion. Concentration of HMMM solution considered to be equal to $1 \%$ was: $\mathrm{Cu}-0.0075 ; \mathrm{Zn}$ 0.064 ; $\mathrm{Ni}-0.0021$; Cr - 0.0028; Pb - 0.0142; Cd - 0.00018; Mn - 0.0099 mg/l correspondingly.

Orimulsion was obtained from Lithuanian Thermal Power Plant. The concentration of oil hydrocarbons was measured using infrared spectroscopy in the $\mathrm{C}-\mathrm{H}$ region of the spectrum after solvent extraction. As well as it was found that water-soluble-fraction (WSF) amounted only $0.009 \%$ of total weight of orimulsion. Whereas WSF of orimulsion made very small part of it and orimulsion itself has the property to disperse in all water volume during very short period of time, no regard was paid to this fraction in toxicity tests.

The concentrations of crude oil were chosen on the ground of our previous studies, which indicated that these concentrations of substances did not cause acute (during $96 \mathrm{~h}$ ) mortality of larvae and adult rainbow trout. Petroleum hydrocarbons were extracted into carbon tetrachloride, then they were separated on the chromatographic column and their concentrations were measured by the AN-1 analyser at wave length $1 / \lambda=2930 \mathrm{~cm}^{-1}$.

The water samples of Lake Druksiai were collected at the following biotopes: $7 \mathrm{a}$ - the zone of the discharge of industrial waste water and storm water into Lake Druksiai; 6a - the zone of the discharge of industrial waste water and treated municipal waste water into Lake Druksiai, 1 - the zone in the Lake Druksiai far from Ignalina Nuclear Power Plant (INPP).

All tests were performed using artesian water of high quality. Average hardness of water was approximately $284 \mathrm{mg} / \mathrm{l}$ as $\mathrm{CaCO}_{3}$, alkalinity was $244 \mathrm{mg} / \mathrm{l}$ as $\mathrm{HCO}_{3}{ }^{-}$, mean pH was equal to 8.0, temperature was about $10 \pm 05^{\circ} \mathrm{C}$, and oxygen concentration ranged from 8 to $10 \mathrm{mg} / \mathrm{l}$.

\title{
2.2 Test-organisms
}

Rainbow trout eggs and adults (one-year-old) were obtained from Zeimena hatchery and acclimated under laboratory conditions.

The tests were started with early-eyed embryos and they were ended before active feeding of larvae. 200-400 embryos were exposed to each concentration of toxicants and two replications were done. During all the tests morphological (total body mass in $\mathrm{mg}$ ), physiological parameters (cardio-respiratory) such as heart rate (HR, counts/min), gill ventilation frequency (VF, counts/min), integrated parameters (relative mass increase in \%) were recorded. Long-term tests on adult fish were performed for 14-28 days. The randomly sorted fish were transferred into aquarium of 100-1 capacity. The control water and toxicants test solutions were renewed every day. During testing fish were fed every day. The body lengths and weights of test fish were measured at the beginning and at the end of exposure. The tissue weights were measured at the end of exposure and tissue-somatic indices: gill-somatic (GSI) and liver-somatic (LSI) of the test fish were calculated [6]. Gill ventilation frequency (GVF, counts/min) and "coughing" rate or gill-cleaning reflex (CR, counts/min) were measured during 3-minute periods for each test fish individually and mean value for 15 fish was calculated.

All acute (96 hours) and long-term (28-70 days) toxicity tests were conducted under semi-static conditions and fish mortality observations were made at 24 -hour intervals. 
The Median acutely lethal concentration (LC50) values and their $95 \%$ confidence intervals were estimated by use of the trimmed SPEARMAN-KARBER method [20].

The Maximum Acceptable Toxicant Concentrations (MATC) were estimated for every parameter by defining geometric mean between the lowest observed effect concentration (LOEC) and the no observed effect concentration (NOEC), the method suggested by Rand and Petrocelli [21].

The significance of all the data obtained was determined by use of STUDENT'S t-test and $\chi^{2}$ with $\mathrm{P} \leq 0.05$.

\section{RESULTS AND DISCUSION}

\subsection{Heavy metals (HM)}

The data obtained (see Table 1) showed that calculated 96h LC50 values for development stages of $O$. mykiss were of $0.36-0.86 \mathrm{mg} / \mathrm{l}$ of $\mathrm{Cu}$, of $0.48-3.8 \mathrm{mg} / \mathrm{l}$ of $\mathrm{Zn}$. Cu was found to be the most toxic. The larvae of $O$. mykiss appeared to be the most sensitive to all tested metals, followed by embryos and adult fish. The comparison of $96 \mathrm{~h} \mathrm{LC50}$ values of $\mathrm{Cu}$ in the test-organisms showed that the given index for the larvae was about 2.4 times lower than for embryos, and 1.8 times lower for adult fish [22].

Table 1. Acute toxicity of HM to rainbow trout at all stages of development.

\begin{tabular}{lcc}
\hline \multicolumn{1}{c}{ Stages of development } & 96-hour LC50 (\%) & 95\% confidence intervald\%) \\
\hline $\mathrm{Cu} \quad$ & 0.86 & $0.80 \div 0.96$ \\
$\quad$ Embryos (eye stage) & 0.36 & $0.3 \div 0.4$ \\
$\quad$ Larvae & 0.65 & $0.6 \div 0.7$ \\
$\quad$ Adult fish & 1.2 & $1.1 \div 1.4$ \\
\hline Zn $\quad 0.48$ & $0.4 \div 0.5$ \\
$\quad$ Embryos (eye stage) & 3.8 & $2.7 \div 5.4$ \\
Larvae & & \\
Adult fish & & \\
\hline
\end{tabular}

On the basin of the obtained data, we have arranged the following sequences of metal toxicity for each development stage of $O$. mykiss and for other test-organisms. The comparison of the sensitivity of rainbow trout and other test-organisms of different phylogenetic level to heavy metals (see Table 2) [22].

Investigations of the impact of heavy metals on test-organisms of different phylogenetic level showed that in most cases $\mathrm{Cu}$ was the most toxic metal to both plants and animals, but $\mathrm{Zn}$, which is one of the least toxic metals to plants, was very toxic to animals. Summing up we can say that it is impossible to single out the most sensitive test-object among those studied that could be universal for the toxicants or at least for their groups. 
Table 2. The sensitivity of rainbow trout and other test-organisms of different phylogenetic level to heavy metals.

Test-organisms

Heavy metals

O. mykiss: (LC50):

$\begin{array}{cl}\text { Embryos } & \mathrm{Cu}>\mathrm{Zn}>\mathrm{Ni}>\mathrm{Fe}>\mathrm{Cr} \\ \text { Larvae } & \mathrm{Cu}>\mathrm{Zn}>\mathrm{Ni}>\mathrm{Fe}>\mathrm{Cr} \\ \text { Adult fish } & \mathrm{Cu}>\mathrm{Zn}>\mathrm{Ni}>\mathrm{Cr}>\mathrm{Fe} \\ 50) & \mathrm{Cr}(\mathrm{VI})>\mathrm{Cu}>\mathrm{Ni}>\mathrm{Zn} \\ \text { EC50) } & \mathrm{Cu}=\mathrm{Cr}(\mathrm{VI})>\mathrm{Ni}>\mathrm{Zn}>\mathrm{Fe}(\mathrm{II}) \\ \text { EC50) } & \mathrm{Ni}>\mathrm{Cu}=\mathrm{Cr}(\mathrm{VI})>\mathrm{Zn} \\ (\text { LC50) } & \mathrm{Cu}>\mathrm{Cr}>\mathrm{Zn}>\mathrm{Ni}>\mathrm{Fe}\end{array}$

L. sativum: (EC50)

S. polyrrhiza: (EC50)

$\mathrm{Cu}>\mathrm{Cr}>\mathrm{Zn}>\mathrm{Ni}>\mathrm{Fe}$

\subsection{Heavy metal model mixture (HMMM)}

Acute toxicity tests were conducted in order to determine basic toxic characteristics of HMMM studied. The results of acute toxicity tests are presented in (see Table 3) However, no significant difference between sensitivity of embryos and adult fish to HMMM was found [23].

Table 3. Acute toxicity of HMMM to rainbow trout at all stages of development

\begin{tabular}{lcc}
\hline \multicolumn{1}{c}{ Stages of development } & 96-hour LC50 (\%) & 95\% confidence intervald\%) \\
\hline Embryos (eye stage) & 26.4 & $22.8 \div 30.6$ \\
Larvae & 9.5 & $8.1 \div 11.2$ \\
Adult fish & 29.3 & $26.5 \div 32.4$ \\
\hline
\end{tabular}

Mortality of aquatic animals is the most significant parameter in toxicology [21]. Comparison of HMMM concentrations induced mortality of test fish as shown in (see Table 3) demonstrated that the most sensitive to HMMM were larvae then followed embryos and adult fish. These data confirmed our earlier conclusions that embryos are more resistant to impact of heavy metal mixtures as compared to larvae stage [12]. Probably embryos chorion as a barrier saves the developing organism from the external harmful impact (including heavy metals), meanwhile larvae of fish, which lost a chorion, are very sensitive to heavy metals as they experience their direct negative effect $[24,12]$. It should be noted that 96 hour LC50 of HMMM to embryos and adult individuals did not differ significantly: $26.4 \%$ - embryos, $29.3 \%$ - adult fish, respectively.

Adult fish were found to be rather sensitive to heavy metal mixture studied as compared to embryos. The statistical evaluation of biological parameters revealed marginally significant difference between embryos and larval MATC values. Only changes in gill ventilation frequency of adult fish were registered at lower concentrations of HMMM. MATC to this parameter was equal to $0.87 \%$ of HMMM, that extremely significantly differed from MATC estimated to embryo heart rate as shown in (see Table 4). Meanwhile no differences were found between 
MATC's of HMMM calculated to ventilation frequencies of larvae and adult fish that confirmed higher sensitivity of larvae and adult fish to external effects as compared to embryos. MATC's of HMMM calculated to respiratory parameters of adult fish $t$ ranged from 1.77 to $3.54 \%$ of HMMM [23].

Table 4. Maximum Acceptable Toxicant Concentrations (MATC) of HMMM to biological parameters of rainbow trout at all stages of development

\begin{tabular}{lc}
\hline \multicolumn{1}{c}{ Stage of development } & MATC (\%) \\
\hline Embryos & 9.3 \\
Heart rate & $2.7^{*}$ \\
\hline Larvae (20-day old) & $2.7^{*}$ \\
Heart rate & $0.49^{*}$ \\
Gill ventilation frequency & \\
Total body mass at the end of tests & $0.87^{*}$ \\
\hline Adult fish & $0.87 \%$ \\
Gill-somatic index & \\
Gill ventilation frequency &
\end{tabular}

* Values significantly diffierent from controls $(\mathrm{P}<0.05)$

The comparison of the physiological responses of rainbow trout exposed to HMMM reveal their sensitivity differences depending on fish stage of development. MATC calculated to such parameters as disturbances in heart rate of embryos, lower heart rate and slowing of ventilation frequency of larvae ranged from 2.7 to $9.3 \%$ of HMMM as shown in (see Table 4). We may presume that as a one negative consequence of disturbances in functioning of respiratory system of organism in early ontogenesis was a decrease in mass of larvae at the end of yolk resorbtion. MATC to this parameter was very low $(0.49 \%$ of HMMM). Our data confirmed that integrated biological parameters like survival, growth rate, development or reproduction indices are the most sensitive to various environmental impacts [25].

The data obtained have shown that fish especially at early stages of development are very sensitive to HMMM impact and our data let predict negative possibilities for survival of future generations of more sensitive fish species that will experience even low level impact of these pollutants. The changes in physiological parameters of embryos exposed to HMMM such as heart rate slowing may induce negative consequences in respiratory process, development and hatching success. Decrease in survival of population is a possible after-effect [26].

\subsection{Orimulsion}

Acute toxicity tests were conducted in order to determine basic toxic characteristics of orimulsion. The results of acute toxicity tests are presented in (see Table 5). The data obtained have shown that the most sensitive to acute toxic effect of orimulsion were larvae, then followed embryos and adult fish. 
Kalmar ECO-TECH' 05 and

The Second Baltic Symposium on Environmental Chemistry

KALMAR, SWEDEN, November 28-30, 2005

Table 5. Acute toxicity of orimulsion to rainbow trout at all stages of development.

\begin{tabular}{lcc}
\hline \multicolumn{1}{c}{ Stage of development } & 96-hour LC50 $(\mathrm{g} / \mathrm{l})$ & $95 \%$ confidence interval $(\mathrm{g} / \mathrm{l})$ \\
\hline Embryos (eye stage) & 0.1 & $0.09-0.12$ \\
Larvae & 0.06 & $0.05 \mathrm{e}-0.07$ \\
Adult fish & 2.22 & $2.02 \mathrm{e}-2.43$ \\
\hline
\end{tabular}

The primary contact of test fish with toxic solutions of orimulsion induced their hyperactivity, although after 24 hours fish became less active. The gills of dead fish were plugged with mucous and small particles of bitumen. It is evident that fish kills occurred due to dispersed and soluble parts of orimulsion [17]. Estimated Maximum Acceptable Toxicant Concentrations (MATC) of total orimulsion for all biological parameters of rainbow trout studied in long-term tests are presented in (see Table 6 ).

Orimulsion (stable emulsion of natural bitumen and water) has the property to disperse in all water volume during short period of time. Its toxic effect on rainbow trout can be characterised by combined effiects of dispersion and water-soluble-fraction. Toxicity tests have shown that the most sensitive to acute toxic effect of orimulsion were larvae, then followed embryos and adult fish. Duration of exposure significantly decreased the value of LC50 in adult fish. Acute toxic effect of orimulsion to rainbow trout can be characterised by very narrow toxic effiect zone and the sharp boundary between lethal and sublethal concentrations.

Table 6. Long-term effects of total orimulsion to rainbow trout at all stages of development

\begin{tabular}{|c|c|}
\hline Parameters & MATC, g/l \\
\hline \multicolumn{2}{|l|}{ Embryos } \\
\hline Heart rate after 5 -day exposure & 0.019 \\
\hline \multicolumn{2}{|l|}{ Larvae } \\
\hline Gill ventilation frequency after 20 -day exposure & 0.008 \\
\hline Heart rate after 20 -day exposure & 0.017 \\
\hline Total body mass at the end of the tests (60-day exposure) & 0.004 \\
\hline Relative mass increase at the end of the tests (60-day exposure) & 0.0017 \\
\hline Hatching duration & 0.07 \\
\hline Amount of hatched larvae & 0.008 \\
\hline Yolk-sac resorbtion & 0.004 \\
\hline Exit off the nest & 0.004 \\
\hline Response of larvae to external stimuli & 0.017 \\
\hline \multicolumn{2}{|l|}{ Adult fish } \\
\hline 28-day LC50 (95\% confidence interval) & $0.26(0.2 \notin-0.32)$ \\
\hline Specific growth rate $(r)$ & 0.09 \\
\hline
\end{tabular}




\author{
Kalmar ECO-TECH '05 and \\ The Second Baltic Symposium on Environmental Chemistry \\ KALMAR, SWEDEN, November 28-30, 2005
}

Maximum Acceptable Toxicant Concentration (MATC) of $0.0017 \mathrm{~g} / \mathrm{l}$ of total orimulsion to fish was derived from long-term tests based on of the most sensitive parameter of rainbow trout larvae (relative mass increase at the end of the test) [17]. Fish at early stages of development are especially sensitive to impact of oil hydrocarbons [27]. We may presume that as a one negative consequence of disturbances in functioning of cardiorespiratory system of organism in early ontogenesis (decrease in heart rate and gill ventilation frequency) was a decrease in mass of larvae at the end of yolk resorbtion [17].

\title{
3.4 Crude oil
}

The exposure of adult fish to crude oil $(1610 \mathrm{mg} / \mathrm{l})$ did not affect their survival. Larval mortality rate increased and at the end of tests it was approximately $\sim 36 \%$. Crude oil significantly $(\mathrm{P}<0.05)$ decreased the average body mass, HR and GVF of larvae at the end of the tests (see Table 7). GVF of adult fish decreased from $93.3 \pm 3.6$ (after a 1-day exposure) to $73.0 \pm 2.0$ count/min after a 4-day exposure [19].

Table 7. The effects of crude oil on biological parameters of larvae of rainbow trout at the end of exposure

\begin{tabular}{lccc}
\hline \multirow{2}{*}{ Compounds } & \multicolumn{3}{c}{ Parameters } \\
\cline { 2 - 4 } & Average body mass $(\mathrm{mg})$ & HR (counts/min) & G VF (counts/min) \\
\hline Crude oil & $98.9 \pm 4.9^{*}$ & $80.6 \pm 4.2^{*}$ & $102.6 \pm 4.1^{*}$ \\
Control & $124.0 \pm 4.2$ & $121.1 \pm 5.4$ & $126.3 \pm 7.0$ \\
\hline
\end{tabular}

* Values significantly diffierent from controls $(\mathrm{P}<0.05)$

Crude oil did not affiect adult fish survival, but larval mortality increased at the end of the tests. Significant alterations in cardio-respiratory parameters of larvae and respiratory indices of adult fish confirmed the specific toxic effect of oil on this system. Oil coats gills of aquatic organisms, inducing pathological lesions on respiratory surfaces, and, thus, causes problems with oxygen supply and respiration [28].

\subsection{Water of various biotopes of Lake Druksiai}

Our data (see Table 8) show that during the study period water of biotopes 1 was not toxic to rainbow trout embryos and larvae: $7.7-10.2 \%$ of embryos and 10.6-12.6\% of larvae died (in the control 7.6-8.3\% and 9.4-10.4\%, respectively), the physiological indices of embryos and larvae were approximately to those of the control (see Table 9). The function of the cardiorespiratory system in this water was at the control level: HR of the embryos - 96.8 counts/min., of the larvae - 106.4 counts $/ \mathrm{min}$; GVF of the larvae was 128.4 counts $/ \mathrm{min}$. The average body mass of larvae was $74.8 \mathrm{mg}$, its relative mass increase at the end of the tests (60-day exposure) being 77\% [29]. 
Kalmar ECO-TECH 05 and

The Second Baltic Symposium on Environmental Chemistry

KALMAR, SWEDEN, November 28-30, 2005

Table 8. The effect of the water of various biotopes Lake Druksiai to rainbow trout embryos and larvae.

\begin{tabular}{lcc}
\hline Lake Druksiai biotopes & Mortality of embryos,e\% & Mortality of larvae,e\% \\
\hline 1 & 7.7 & 10.6 \\
6a & 20.3 & 28.6 \\
$7 \mathrm{a}$ & 10.6 & 18.6 \\
Control & 8.3 & 10.4 \\
\hline
\end{tabular}

In the water of Lake Druksiai biotopes were observed changes in the physiological state of larvae (seeoTable 9). The HR of the embryos in the water of both biotopes 6 a and $7 \mathrm{a}$ was approximately similar to those in the control. Meanwhile, we observed changes in the cardiorespiratory system of larvae: HR and GVF increased, the average body mass was less than in the control, relative body mass increase at the end of the tests (60-day exposure) being only $40-47 \%(80 \%$ in the control)e

Table 9. The effect of the water of various Lake Druksiai biotopes to the physiological parameters of rainbow trout embryos and larvae.

\begin{tabular}{|c|c|c|c|c|c|}
\hline \multirow[b]{3}{*}{$\begin{array}{l}\text { Lake } \\
\text { Druksiai } \\
\text { biotopes }\end{array}$} & Embryos & \multicolumn{4}{|c|}{ Larvae } \\
\hline & \multicolumn{5}{|c|}{ Parameters } \\
\hline & $\begin{array}{c}\mathrm{HR}, \\
\text { counts/min }\end{array}$ & $\begin{array}{c}\mathrm{HR}, \\
\text { counts/min }\end{array}$ & $\begin{array}{c}\text { GVF, } \\
\text { counts/min }\end{array}$ & $\begin{array}{c}\text { Average } \\
\text { body mass, } \\
\text { mg }\end{array}$ & $\begin{array}{l}\text { Relative mass } \\
\text { increase at the end of } \\
\text { the tests ( } 60 \text {-day } \\
\text { exposure) }\end{array}$ \\
\hline 1 & $96.8 \pm 2.4$ & $106.4 \pm 2.8$ & $128.4 \pm 2.2$ & $74.8 \pm 2.4$ & 77 \\
\hline $6 a$ & $99.4 \pm 2.2$ & $132.4 \pm 3.6^{*}$ & $142.2 \pm 2.6^{*}$ & $64.2 \pm 2.2^{*}$ & 45 \\
\hline $7 a$ & $94.4 \pm 1.8$ & $122.6 \pm 2.6^{*}$ & $138.2 \pm 2.4^{*}$ & $68.4 \pm 1.8^{*}$ & 47 \\
\hline Control & $98.4 \pm 2.4$ & $110.4 \pm 4.2$ & $126.4 \pm 3.6$ & $76.4 \pm 1.8$ & 80 \\
\hline
\end{tabular}

* Values significantly different from controls $(\mathrm{P}<0.05)$

The results allow conclude that the waters of the Lake Druksiai biotopes 6a, 7a were not favorable for the normal growth and development of larvae. The observed changes show that the INPP effluents bring into Lake Druksiai toxicants that cause alterations in the physiological systems of test-organisms, slowing their growth and development and even causing their death.

The water patterns from some biotopes of Lake Druksiai (biotopes 6a, 7a) produced toxic effect to organisms as well. Therefore the chemical substances entering with different origin waste waters predetermine the toxicity of the Water Lake Druksiai observed in our experiments. INPP wastewaters consist of many components, such as heavy metals, radionuclides, alkalies and solutions diluted with acids, weak organic acids, oil products etc. The concentration of each component in various biotopes of reservoir can be different and changes constantly. Amount of heavy metals in lake Druksiai increased after INPP operational start: copper, zinc, manganese, chromium, cadmium, nickel, iron increased from two and half to forty times in some water biotopes of lake Druksiai $[8,30]$. The data obtained testing of the water of some biotopes of Lake 


\section{Kalmar ECO-TECH '05 and \\ The Second Baltic Symposium on Environmental Chemistry \\ KALMAR, SWEDEN, November 28-30, 2005}

Druksiai have shown that all the discharged waters entering in the lake are more or less harmful to rainbow trout $(O$. mykiss $)$ embryos and larvae.

\section{CONCLUSIONS}

Our study demonstrated that the fish (rainbow trout) was very sensitive test-organism to the effect of different kind pollutants (some heavy metals, heavy metal model mixture, orimulsion, crude oil and water of some biotopes of Lake Druksiai. The most sensitive to the impact of pollutants were fish at early stages of development i.e. larvae and embryos. The integrated biological parameters of fish at all stages of development (survival, growth rate, and relative mass increase) were the most sensitive ones. In accordance with the sensitivity to the impact of heavy metals, animals in the earliest stages of their development were more sensitive than plants, but the plants in some cases were more sensitive to heavy metals than adult fish. Therefore, plants as well as animals (O. mykiss) of different life stages, as test-organisms, are recommended for the inclusion of the complex biotests for the assessment of the impact of heavy metals. The complex of the most sensitive parameters investigated of rainbow trout can be successfully used for the water toxicity assessment containing different kind pollutants. The data obtained let predict the impact of pollution not only to the physiological status of aquatic organisms but as well as to their survival in natural water bodies.

\section{REFERECES}

[1] Eisler R., 1993. Zinc hazards to fish, wildlife, and invertebrates: a synoptic review. U.S. Fish and Wildlife S Biological Report. 10. 106.

[2] Eisler R., 1998. Copper hazards to fish, wildlife, and invertebrates: a synoptic review. Biological Science Report USGS/BRD/BSR/. 1997-0002. 99.

[3] Kloepper-Sams P.J., Swanson, S.M., Marchant T., Schryer R., Owens J.W., 1994. Exposure of fish to biologically treated bleached-kraft effluent. 1. Biochemical, physiological and pathological assessment of rocky mountain whitefish (Proso pium Williamsoni) and longnose sucker (Catostomus catostomus). Environ. Toxicol. Chem. 13(9), 1469-1482.

[4] Vosyliené M.Z., Svecevičius G., Šyvienè S., 1994. Toxicity of Factory Wastewaters and Heavy Metal Solutions to Rainbow Trout. In: R.V. Thurston (Ed.), Environmental Studies in the Nemunas River Basin, Lithuania. US EPA/600/R-94/155. 107-115.

[5] Canna-Michaelidou ST., Nicolaou A.S., Neophytou E., Christodoulidou M., 1999. Toxicity testing for effective monitoring and sustainability of aquatic environment. In: SECOTOX 99, Fifth European Conference on Ecotoxicology and Environmental Safety, Neuherberg/Munich, Germany. O D1.

[6] Vosylienè M.Z., Svecevičius G., 1997. Sublethal Effects on Rainbow Trout of Chronic Exposures to Mixtures of Heavy Metals. In: R.V. THURSTON (Ed.), Fish Physiology, Toxicology, and Water Quality. US EPA/600/R-9ð/098. 141-151.

[7] Kazlauskienè N., Svecevičius G., Vosyliené M.Z., Marčiulionienè D., Montvydienè D., 2004. Comparative study on sensitivity of higher plants and fish to heavy fuel oil. Environ. Toxicol, 19 (4), 449-451.

[8] Kazlauskienè N., Burba A., Svecevičius G., 1996. Reactions of hydrobionts on effect of mixture of five galvanic heavy metals. Ekologija. 4, 56-59. 
[9] Kazlauskienè N., Stasiūnaite P., 1999. The lethal and sublethal effect of heavy metal mixture on rainbow trout (Oncorhynchus mykiss). Acta Zoologica Lithuanica. 9(2), 47-56.

[10] Vosylienè, MZ., Kazlauskienè, N., Svecevičius, G., 2003. Complex Study into the Effect of Heavy Metal Model Mixture on Biological Parameters of Rainbow Trout Oncorhynchus mykiss. Environ Sci \& Pollut Res.10, 103-107.

[11] Birge W.J., Black J.A., 1979. Effects of copper on embryonic and juvenile stages of aquatic animals. In: NRIAGU J.O. (Ed.), Copper in the environment. Part 2: health effects. John Wiley. New York. 373-399.

[12] Kazlauskienė N., Burba A., Svecevičius G., 1994. Acute toxicity of five galvanic heavy metals to hydrobionts. Ekologija. 1, 33-36.

[13] Kazlauskiené N., Svecevičius G., Vosylienè M.Z., 1999. The use of rainbow trout (Oncorhynchus mykiss) as a test-object for evaluation of the water quality polluted with heavy metal. In: Metals in the Environment: an integrated approach, ed. by D. Lovejoy. Vilnius, 231-234.

[14] Kazlauskienè N., 2002. Long-term effect of copper on sea trout (Salmo trutta trutta L.) in early ontogenesis. Ekologija. 2, 65-69.

[15] Vosylienè M. Burba A., Kazlauskienė N., Petrauskienè L., Svecevičius G., Stasiūnaite P., 1999. The complex studies of biological effects of heavy metal mixtures on aquatic organisms. In: Metals in the Environment: an integrated approach, ed. by D. Lovejoy. Vilnius, 213-216.

[16] Kazlauskiene N., 2004. Classification and possible consequences of the sublethal effiects of heavy metal model mixture in fish at early ontogenesis. Ed. M. Anke et al. 22. Workshop 2004. Macro and Trace Elements; Mengen- and Spurenelemente. SCHUBERT-Verlag, Leipzig. 1. Auflage, 1172-1177.

[17] Svecevičius G. Kazlauskienè N., Vosylienè M.Z., 2003. Toxic effects of orimulsion on rainbow trout Oncorhynchus mykiss. Environ. Sci. \& Pollut. Res. 10 (5), 281-283.

[18] Kazlauskienė N., Svecevičius G., Vosylienè M. Z., Marčiulionienè D., Montvydienè D. (2004) Comparative Study of Higher Plants and Fish to Heavy Fuel Oil. Wiley Periodicals. Inc. Environmental Toxicology. 19, 449-451.

[19] Vosyliené M.Z., Kazlauskienė N., Jokšas K., 2005. Toxic effects of crude oil combined with oil cleaner simple green on yolk-sac larvae and adult rainbow trout Oncorhynchus mykiss. Environ. Sci. \& Pollut. Res. 12 (3), 136-139.

[20] Hamiltos M.A., Russo R.C., Thurston R.V., 1977. Trimmed SPEARMAN-KARBER method for estimating median lethal concentrations in toxicity bioassays. Environ. Sci. Technol. 11, 714- 719

[21] Rand G.M., Petrocelli S.R. (Eds), 1985. Fundamentals of Aquatic Toxicology. Hemisphere Publ. Corp. New York, 666.

[22] Marčiulioniené, Montvydienè D., Kazlauskienè N., Svecevičius G., 2002. Comparative analysis of the sensitivity of test-organisms of different phylogenetic level and life stages to heavy metals. Environmental and Chemical Physics. 24 (2), 73-78.

[23] Vosyliené, M. Z., Kazlauskiené, N., Svecevičius, G., 2003. Complex Study into the Effect of Heavy Metal Model Mixture on Biological Parameters of Rainbow Trout Oncorhynchus mykiss. Environmental Science and Pollution Research. 10 (2), 103-107.

[24] Jezierska B., Slominska I., 1997. The effect of copper on common carp (Cyprinus carpio L.) during embryonic and postembryonic development. Pol. Arch. Hydrobiol. 44, 261-272.

[25] Sindermann, C.J., 1984. Fish and environmental impact. Arch. Fish Wiss. 35(1), 125-160. 
[26] McKIM, J.M., 1985. Early life stage toxicity tests. In: Rand G.M. and Petrocelli S.R. (Eds.), Fundamentals of Aquatic Toxicology. Hemisphere Publ.Corp. New York. 48-95.

[27] Levin, SA., Harwell, MA., Kelly JR., Kimball, KD., 1989. Ecotoxicology: problems and approaches. New York, Springer-Verlag. 545o

[28] Hoong Gin KY, Huda, KM, Lim, WK., Tkalich, P., (2001) An oil spill-food chain interaction model for coastal waters. Marine Pollut Bull. 42(7), 590-597.

[29] Kazlauskienè N., Čepulienè Ž., 1998. Ecotoxicity of Lake Druksiai waters assessed by biotesting with rainbow trout spawn and larvae. Proceedings. Latvian Academy of Sciences. Sect. B, 52, Supplement. 126-129.

[30] Marciulioniene, D., Kazlauskiene, N., Svobiene, R., 1995. Evaluation of Ignalina NPP waste matters toxicity by use of biotest complex. In: The impact of the Ignalina Nuclear Power Plant on Nature and Society. Collection of Scientific Papers.Vilnius, 116-125 (in Lithuanian). 